\title{
SCREENING METHODS TO DETERMINE ANTIBACTERIAL ACTIVITY OF NATURAL PRODUCTS
}

\author{
Cleidson Valgas ${ }^{1}$; Simone Machado de Souza²; Elza F A Smânia²; Artur Smânia Jr. ${ }^{2 *}$ \\ ${ }^{1}$ Universidade do Sul de Santa Catarina, Tubarão, SC, Brasil; ${ }^{2}$ Laboratório de Antibióticos, Universidade Federal de Santa \\ Catarina, Florianópolis, SC, Brasil
}

Submitted: April 07, 2006; Returned to authors for corrections: September 06, 2006; Approved: February $23,2007$.

\begin{abstract}
The emergence of new infectious diseases, the resurgence of several infections that appeared to have been controlled and the increase in bacterial resistance have created the necessity for studies directed towards the development of new antimicrobials. Considering the failure to acquire new molecules with antimicrobial properties from microorganisms, the optimization for screening methods used for the identification of antimicrobials from other natural sources is of great importance. The objective of this study was to evaluate technical variants used in screening methods to determine antibacterial activity of natural products. Thus, a varied range of natural products of plant, fungi and lichen origin were tested against two bacterial species, Staphylococcus aureus ATCC 25923 and Escherichia coli ATCC 25922, by two variants of the agar diffusion method (well and disc), two variants of the bioautographic method (direct and indirect) and by microdilution assay. We concluded that the well-variant of the diffusion method was more sensitive than the disc-variant, whilst the direct-variant of the bioautographic method exhibited a greater sensitivity if compared to indirectvariant. Bioautographic and diffusion techniques were found to have similar sensitivity; however the latter technique provided more suitable conditions for the microbial growth. In this study, we also discussed the best conditions for the determination of minimal inhibitory concentration.
\end{abstract}

Key words: agar diffusion, antimicrobial activity, bioautographic methods, minimum inhibitory concentration, minimum bactericidal concentration, natural products

\section{INTRODUCTION}

Because of available antimicrobials failure to treat infectious diseases, many researchers have focused on the investigation of natural products as source of new bioactive molecules $(15,17)$. A variety of methods are found for this purpose and since not all of them are based on same principles, results obtained will also be profoundly influenced not only by the method selected, but also by the microorganisms used to carry out the test, and by the degree of solubility of each test-compound $(20,16)$. The test systems should ideally be simple, rapid, reproducible, and inexpensive and maximize high sample throughput in order to cope with a varied number of extracts and fractions. The complexity of the bioassay must be defined by laboratory facilities and quality available personnel $(8,11)$.
The currently available screening methods for the detection of antimicrobial activity of natural products fall into three groups, including bioautographic, diffusion, and dilution methods. The bioautographic and diffusion methods are known as qualitative techniques since these methods will only give an idea of the presence or absence of substances with antimicrobial activity. On the other hand, dilution methods are considered quantitative assays once they determine the minimal inhibitory concentration (20). Antimicrobial activities reported in the literature have been evaluated with diverse sets of methodologies, degrees of sensitivity, amount of testcompounds and microbial strains, often difficult to compare. For this reason, our purpose is to suggest some recommendations and establish criteria for the use of bioautographic and diffusion methods.

*Corresponding Author. Mailing address: Laboratório de Antibióticos, Universidade Federal de Santa Catarina, Caixa Postal 476, 88040-900, Florianópolis, SC, Brasil. Tel.: (48) 3331-5210. E-mail: smania@mbox1.ufsc.br 


\section{MATERIALS AND METHODS}

\section{Tested natural products}

Fourteen extracts, seven fractions (obtained by partitioning and chromatographic fractioning of crude extracts) and 10 pure compounds from natural resources were tested (Table 1). The fungi derivatives were supplied by Laboratório de Antibióticos, Universidade Federal de Santa Catarina, plant derivatives were kindly provided by Professor Moacir Geraldo Pizzolatti (Universidade Federal de Santa Catarina) and lichen derivatives by Professor Neli Honda (Universidade Federal de Mato Grosso do Sul). Natural products used were selected by previous antimicrobial activity screening using diffusion method against at least one of the two bacterial strains used during the testing. The solvents used (dichloromethane P.A. - Nuclear, dimethylsulphoxide P.A. - Nuclear, and ethanol P.A. - Grupo Química) to dissolve and dilute the natural products depended on the method used to evaluate their activity. For the diffusion method well-variant, the solvent used was dimethylsulfoxide (DMSO) and for the remaining methodologies, suitable solvents were used for the dissolution of the natural products. Thus, alcohol, water:alcohol and ethyl-acetate fractions, and pure compounds were dissolved and diluted with ethanol:water (8:2). Chloroform and dichloromethane extracts and fractions were dissolved and diluted with ethanol:dichloromethane (8:2), hexane, and petroleum-ether extracts and fractions were dissolved and diluted with ethanol: dichloromethane (6:4).

\section{Test-bacteria}

The antibacterial activity of natural products was assessed against two bacteria species: Staphylococcus aureus ATCC 25923 (American Type Culture Collection, Rockville, MD) and Escherichia coli ATCC 25922, maintained in BHI at $-20^{\circ} \mathrm{C} ; 300$ $\mathrm{mL}$ of each stock-culture were added to $3 \mathrm{~mL}$ of BHI broth. Overnight cultures were kept for $24 \mathrm{~h}$ at $36^{\circ} \mathrm{C} \pm 1{ }^{\circ} \mathrm{C}$ and the purity of cultures was checked after $8 \mathrm{~h}$ of incubation. After 24 $\mathrm{h}$ of incubation, bacterial suspension (inoculum) was diluted with sterile physiological solution, for the diffusion and indirect bioautographic tests, to $10^{8} \mathrm{CFU} / \mathrm{mL}$ (turbidity $=\mathrm{McFarland}$ barium sulfate standard 0.5). For the direct bioautographic test, bacterial suspension was diluted with BHI broth to a density of approximately $10^{9} \mathrm{UFC} / \mathrm{mL}$ (McFarland standard 3).

\section{Indicator solution for determination of bacterial growth}

A 70\% ethanolic solution of 2-(4-iodophenyl)-3-(4nitrophenyl)-5-phenyltetrazolium chloride (INT) $(2 \mathrm{mg} / \mathrm{mL})$ purchased from Sigma was used for the bacterial growth tests.

\section{Evaluated methods}

In order to suggest methodologies for screening the natural products antimicrobial activity, two different qualitative methods were evaluated as follows: agar diffusion test, employing two different types of reservoirs (filter paper disc impregnated with compound-test and wells in dishes) and bioautographic method (agar diffusion and chromatogram layer). Besides, we discussed the aspects of the microdilution method used for the determination of minimum inhibitory concentration (MIC).

\section{Agar diffusion well-variant}

The bacterial inoculum was uniformly spread using sterile cotton swab on a sterile Petri dish MH agar. Nine serial dilutions yielded concentrations of $100,80,60,40,20,10,5,2.5$, and 1.25 $\mathrm{mg} / \mathrm{mL}$ for extracts and fractions and four serial dilutions yielded concentrations of $20,15,10$ e $5 \mathrm{mg} / \mathrm{mL}$ for pure substances. 50 $\mu \mathrm{L}$ of natural products were added to each of the 5 wells $(7 \mathrm{~mm}$ diameter holes cut in the agar gel, $20 \mathrm{~mm}$ apart from one another). The systems were incubated for $24 \mathrm{~h}$ at $36^{\circ} \mathrm{C} \pm 1^{\circ} \mathrm{C}$, under aerobic conditions. After incubation, confluent bacterial growth was observed. Inhibition of the bacterial growth was measured in $\mathrm{mm}$. Reference commercial discs were used (chloramphenicol $30 \mathrm{mg}$ purchased from $\mathrm{Cecon}^{\circledR}$ and vehicle, $50 \mathrm{~mL}$ ). Tests were performed in duplicate (18).

\section{Agar diffusion disc-variant}

Natural products were dissolved and diluted with solvents as mentioned previously. Same number of subsequent dilutions was performed as described above. However, natural products serial dilutions were performed out of initial concentrations 2.5 greater than the ones performed for well-variant method (i.e. $250 \mathrm{mg} / \mathrm{mL}$ for extracts and fractions and $50 \mathrm{mg} / \mathrm{mL}$ for pure substances); $7 \mathrm{~mm}$ filter paper discs (Whatman, no. 3) were impregnated with $20 \mathrm{~mL}$ of each of the different dilutions. The discs were allowed to remain at room temperature until complete diluent evaporation and kept under refrigeration until ready to be used. Discs loaded with natural products were placed onto the surface of the agar. Commercial chloramphenicol discs (30 $\mathrm{mg}$ ) and paper discs impregnated with $20 \mathrm{~mL}$ of diluents used to dilute natural products were used as control. Tests were performed in duplicate (20).

\section{Bioautographic method direct-variant (chromatogram layer)}

Direct variant of the bioautographic method carried out in this work is outlined as follows: (1) preparation and application of natural products on thin layer chromatography plates (TLC) (silica gel $\mathrm{G}_{60} \mathrm{~F}_{254}$, Merck); (2) preparation and application of the bacterial inoculum to TLC plates; (3) incubation; and (4) growth detection by colorimetric assay (INT) and measurement of growth inhibition diameters. In the first step, $10 \mathrm{~mL}$ of extracts, fractions and pure substances (dissolved and diluted as mentioned previously) were applied to TLC plates as a spot corresponding to 400, 200 and $100 \mathrm{mg}$, respectively. The natural products which displayed some activity were diluted to concentrations that varied from 400 to $50 \mathrm{mg}$ for extracts, 200 to 
Table 1. Natural products used for the evaluation of methodologies to determine antibacterial activity.

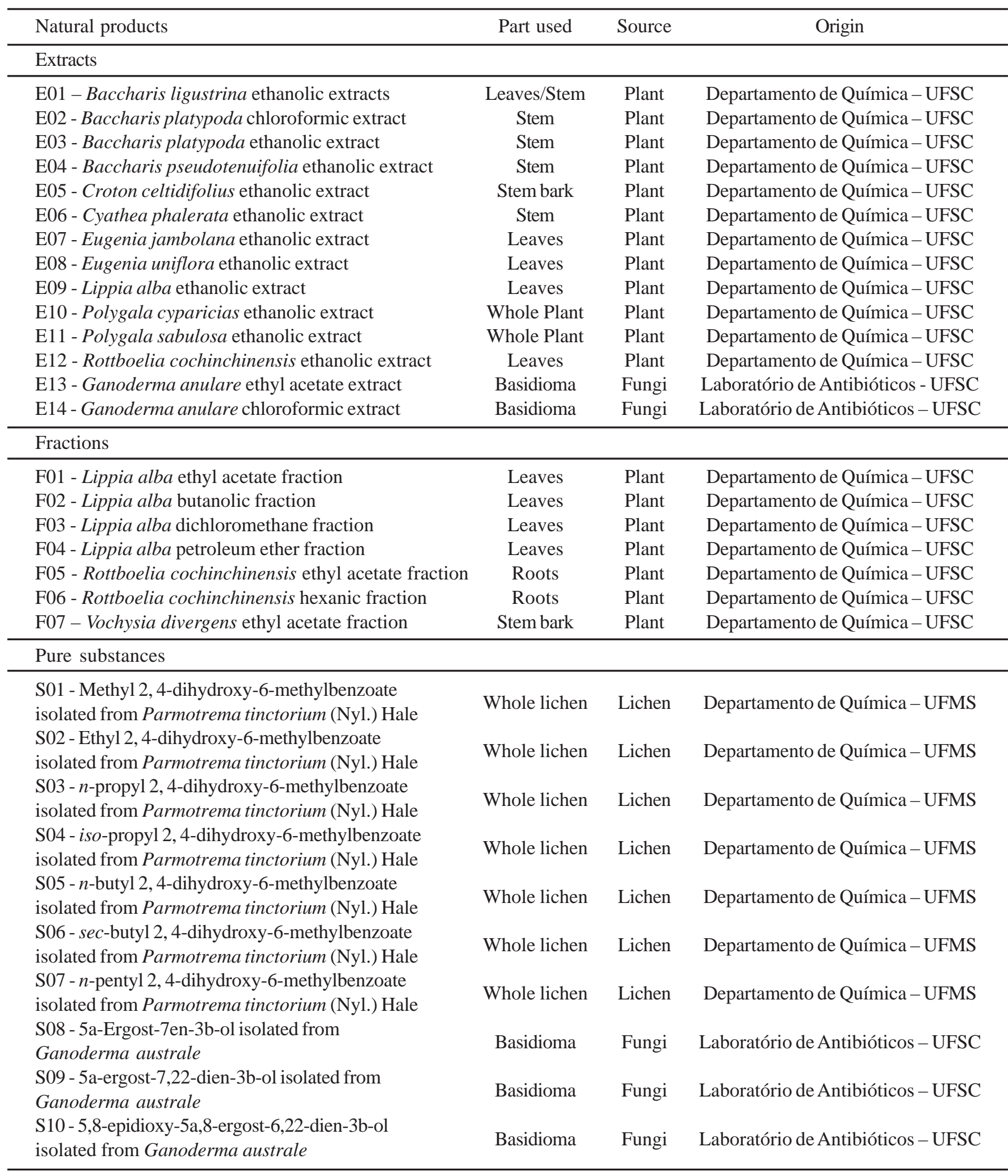

UFSC: Universidade Federal de Santa Caarina; UFMS: Univesidade Federal de Mato Grosso do Sul. 
$25 \mathrm{mg}$ for fractions and 100 to $12.5 \mathrm{mg}$ for pure substances. Each sample spot was located about $2 \mathrm{~cm}$ apart and away from the bottom of TLC plate. Sample spots were performed with a micropipette, thus the spot diameter was about $4 \mathrm{~mm}$. One 6 X 6 $\mathrm{cm}$ TLC plate was used for each test with four test-samples; 20 $\mathrm{mg}$ of chloramphenicol dissolved in $10 \mathrm{~mL}$ of DMSO and $10 \mathrm{~mL}$ aliquots of solvents were applied to plates as control. In step 2, bacterial inoculum was prepared as previously mentioned and transferred to a sterile Petri plate. The TLC plates loaded with the natural products were covered twice with bacterial suspension for $5 \mathrm{~s}$. Excess of suspension was removed and the TLC plate placed into another sterile Petri plate. In step 3, systems were incubated for $24 \mathrm{~h}$ at $36^{\circ} \mathrm{C} \pm 1{ }^{\circ} \mathrm{C}$ inside a hermetically closed polyethylene box. A Becker flask containing a water embedded cotton ball was placed beside the plates for keeping the air inside under moist conditions. In step 4, TLC plates were sprayed with $1 \mathrm{~mL}$ salt solution of $p$ iodonitrotetrazolium violet (INT). Plates were incubated for more $4 \mathrm{~h}$ and the inhibition diameter zones were observed and measured in mm hour after hour $(2,9)$.

Considering the variations found in the literature for the development of bioautographic method direct variant, we performed tests with 24 and 48 h grown culture of Staphylococcus aureus and with three different indicator solution concentrations (INT) to establish appropriate conditions for the execution of this method. Tests using bacterial inoculum and INT concentrations were performed in triplicate $(9,13)$.

\section{Bioautographic method indirect-variant (agar diffusion)}

In this procedure, first step corresponded to bioautographic variant-direct step 1 . In step 2, TLC plates were covered with Müeller-Hinton agar layer $\left(9 \mathrm{~mL}\right.$ of the medium on $81 \mathrm{~cm}^{2}$ petri plate area). However, contact between bacterial suspension and natural products were performed by two distinct procedures: mixing with agar $(100 \mathrm{~mL}$ test-bacterial suspensions were mixed with $9 \mathrm{~mL}$ of agar and carefully poured on TLC plate) and swabbing with a cotton swab (inoculum was spread on the agar surface as described previously). Only the extracts evaluated in this procedure were tested with two types of bacterial inoculum and all tests were carried out in duplicate. In order to compare between the two variants of bioautographic method, results obtained with the use of "pour plate" technique (bacterial suspension mixed with agar) were validated $(1,4)$.

\section{Minimum inhibitory concentration (MIC) determination}

The antibacterial activity of natural products was studied by employing a microdilution method, using two different culture media: Mueller-Hinton broth and Luria Bertania (LB). The inoculum was prepared as described previously. Natural products were dissolved in DMSO (10\% of the final volume) and diluted with culture broth to a concentration of $2 \mathrm{mg} / \mathrm{mL}$.
Further 1:2 serial dilutions were performed by addition of culture broth to reach concentrations ranging from 2 to $0.0156 \mathrm{mg} / \mathrm{mL}$; $100 \mu \mathrm{L}$ of each dilution were distributed in 96-well plates, as well as a sterility control and a growth control (containing culture broth plus DMSO, without antimicrobial substance). Each test and growth control well was inoculated with $5 \mu \mathrm{L}$ of a bacterial suspension $\left(10^{8} \mathrm{CFU} / \mathrm{mL}\right.$ or $\left.10^{5} \mathrm{CFU} / \mathrm{well}\right)$. All experiments were performed in triplicate and the microdilution trays were incubated at $36^{\circ} \mathrm{C}$ for $18 \mathrm{~h}$. Bacterial growth was detected former by optical density (ELISA reader, CLX800-BioTek Instruments) and after by addition of $20 \mu \mathrm{L}$ of an INT alcoholic solution $(0.5$ $\mathrm{mg} / \mathrm{mL}$ ) (Sigma). The trays were again incubated at $36^{\circ} \mathrm{C}$ for 30 min, and in those wells, where bacterial growth occurred, INT changed from yellow to purple. MIC values were defined as the lowest concentration of each natural product, which completely inhibited microbial growth. The results were expressed in milligrams per milliliters (19).

\section{Statistical evaluation}

Results were expressed as mean value \pm standard error of the mean (SEM) of growth inhibition zones diameters obtained with those natural products which amount was sufficient to perform repetitions. Statistical differences between the two variants of diffusion method and two variants of bioautographic method were detected by analysis of variance (ANOVA) followed by Duncan test when required. The Student's T-test was used to compare results between the two assays: the direct variant bioautographic method (performed with 24 and $48 \mathrm{~h} S$. aureus grown cultures) and indirect variant of bioautographic method (performed with both type of inocula). $\mathrm{P}$ values lower than $0.05(\mathrm{p}<0.05)$ were considered significant.

\section{RESULTS}

According to Table 2, of the 14 extracts tested by the two variants of the agar diffusion method employed in this work, 9 $(64.3 \%)$ yielded larger zones of inhibition growth for $S$. aureus when variant-well was used, [GL $(28,29) ; \mathrm{F}=36,06 ; \mathrm{p}<0.01$ ]. For statistical analysis of the data, only results obtained with 5 $\mathrm{mg}$ extracts or fractions were used. The results obtained from remaining five extracts did not present significant difference among the diffusion method variants to assessed degree of significance. Also, four of the seven fractions (57.1\%) tested using well variant demonstrated significant differences [GL (14, 15); $F=11,83 ; p<0.01]$ for $S$. aureus. Test repetitions with pure substances were not possible due to insufficient amount, thus, statistical comparisons for each pure substance separately was not performed. The results of the tests developed with $E$. coli have also pointed to a better sensibility for diffusion method variant-well (Table 3) $(\mathrm{p}<0.05)$. Thus, diffusion method well variant proved to be more sensitive than the natural products loaded disc variant (Table 3). 
Table 2. Means of inhibition growth diameter obtained by diffusion method (well and disc variants) using different concentrations of natural product against Staphylococcus aureus.

\begin{tabular}{|c|c|c|c|c|c|c|c|c|c|c|c|c|c|c|c|c|c|c|c|c|}
\hline \multirow{3}{*}{$\begin{array}{l}\text { Natural } \\
\text { product }\end{array}$} & \multicolumn{20}{|c|}{ Concentration (mg/well or disc) } \\
\hline & \multicolumn{2}{|c|}{5} & \multicolumn{2}{|c|}{4} & \multicolumn{2}{|c|}{3} & \multicolumn{2}{|r|}{2} & \multicolumn{2}{|c|}{1} & \multicolumn{2}{|c|}{0.75} & \multicolumn{2}{|c|}{0.5} & \multicolumn{2}{|c|}{0.25} & \multicolumn{2}{|c|}{0.125} & \multicolumn{2}{|c|}{0.0625} \\
\hline & $\mathrm{W}^{\mathrm{a}}$ & $\mathrm{D}^{\mathrm{a}}$ & $\mathrm{W}$ & $\mathrm{D}$ & $\mathrm{W}$ & $\mathrm{D}$ & $\mathrm{W}$ & $\mathrm{D}$ & $\mathrm{W}$ & $\mathrm{D}$ & $\mathrm{W}$ & $\mathrm{D}$ & $\mathrm{W}$ & $\mathrm{D}$ & $\mathrm{W}$ & $\mathrm{D}$ & $\mathrm{W}$ & $\mathrm{D}$ & $\mathrm{W}$ & $\mathrm{D}$ \\
\hline \multicolumn{21}{|l|}{ Extracts } \\
\hline $\mathrm{E} 01$ & 22 & 12 & 19 & 11 & 16 & 10 & 14 & 10 & 12 & 9 & NT & NT & 11 & 0 & 0 & 0 & 0 & 0 & 0 & 0 \\
\hline $\mathrm{E} 02$ & 12 & 0 & 12 & 0 & 12 & 0 & 11 & 0 & 10 & 0 & NT & NT & 0 & 0 & 0 & 0 & 0 & 0 & 0 & 0 \\
\hline $\mathrm{E} 03$ & 22 & 11 & 19 & 11 & 18 & 10 & 17 & 9 & 16 & 9 & NT & NT & 10 & 0 & 9 & 0 & 0 & 0 & 0 & 0 \\
\hline E04 & 16 & 12 & 14 & 11 & 13 & 11 & 13 & 10 & 11 & 9 & NT & NT & 0 & 0 & 0 & 0 & 0 & 0 & 0 & 0 \\
\hline E05 & 23 & 16 & 22 & 15 & 20 & 14 & 20 & 13 & 16 & 11 & NT & NT & 12 & 9 & 11 & 0 & 9 & 0 & 0 & 0 \\
\hline E06 & 17 & 11 & 16 & 11 & 15 & 10 & 14 & 9 & 13 & 9 & NT & NT & 11 & 0 & 0 & 0 & 0 & 0 & 0 & 0 \\
\hline E07 & 20 & 15 & 19 & 13 & 18 & 12 & 16 & 11 & 14 & 9 & NT & NT & 13 & 0 & 13 & 0 & 12 & 0 & 9 & 0 \\
\hline E08 & 21 & 18 & 20 & 17 & 19 & 17 & 18 & 15 & 16 & 14 & NT & NT & 14 & 12 & 12 & 10 & 9 & 0 & 0 & 0 \\
\hline E09 & 18 & 20 & 17 & 19 & 16 & 17 & 15 & 12 & 11 & 9 & NT & NT & 0 & 0 & 0 & 0 & 0 & 0 & 0 & 0 \\
\hline E10 & 10 & 0 & 0 & 0 & 0 & 0 & 0 & 0 & 0 & 0 & NT & NT & 0 & 0 & 0 & 0 & 0 & 0 & 0 & 0 \\
\hline E11 & 12 & 0 & 11 & 0 & 10 & 0 & 10 & 0 & 0 & 0 & NT & NT & 0 & 0 & 0 & 0 & 0 & 0 & 0 & 0 \\
\hline E12 & 10 & 0 & 0 & 0 & 0 & 0 & 0 & 0 & 0 & 0 & NT & NT & 0 & 0 & 0 & 0 & 0 & 0 & 0 & 0 \\
\hline E13 & 10 & 9 & 10 & 0 & 9 & 0 & 0 & 0 & 0 & 0 & NT & NT & 0 & 0 & 0 & 0 & 0 & 0 & 0 & 0 \\
\hline E14 & 10 & 0 & 9 & 0 & 9 & 0 & 9 & 0 & 0 & 0 & NT & NT & 0 & 0 & 0 & 0 & 0 & 0 & 0 & 0 \\
\hline \multicolumn{21}{|l|}{ Fractions } \\
\hline F01 & 18 & 14 & 18 & 14 & 16 & 12 & 14 & 11 & 11 & 10 & NT & NT & 0 & 0 & 0 & 0 & 0 & 0 & 0 & 0 \\
\hline F02 & 18 & 13 & 17 & 13 & 15 & 12 & 13 & 10 & 10 & 0 & NT & NT & 0 & 0 & 0 & 0 & 0 & 0 & 0 & 0 \\
\hline F03 & 11 & 9 & 10 & 9 & 10 & 0 & 9 & 0 & 0 & 0 & NT & NT & 0 & 0 & 0 & 0 & 0 & 0 & 0 & 0 \\
\hline F04 & 12 & 12 & 12 & 12 & 11 & 11 & 11 & 11 & 9 & 10 & NT & NT & 0 & 0 & 0 & 0 & 0 & 0 & 0 & 0 \\
\hline F05 & 18 & 11 & 17 & 10 & 15 & 9 & 14 & 0 & 9 & 0 & NT & NT & 0 & 0 & 0 & 0 & 0 & 0 & 0 & 0 \\
\hline F06 & 10 & 10 & 9 & 9 & 9 & 9 & 0 & 0 & 0 & 0 & NT & NT & 0 & 0 & 0 & 0 & 0 & 0 & 0 & 0 \\
\hline F07 & 13 & 0 & 12 & 0 & 12 & 0 & 12 & 0 & 12 & 0 & NT & NT & 12 & 0 & 10 & 0 & 0 & 0 & 0 & 0 \\
\hline \multicolumn{21}{|c|}{ Substances $^{b}$} \\
\hline S01 & NT & NT & NT & NT & NT & NT & NT & NT & 20 & 12 & 18 & 11 & 14 & 11 & 0 & 11 & NT & NT & NT & NT \\
\hline $\mathrm{S} 02$ & NT & NT & NT & NT & NT & NT & NT & NT & 15 & 9 & 14 & 9 & 14 & 9 & 10 & 9 & NT & $\mathrm{Nt}$ & NT & NT \\
\hline $\mathrm{S} 03$ & NT & NT & NT & NT & NT & NT & NT & NT & 12 & 10 & 12 & 10 & 12 & 10 & 12 & 10 & NT & NT & NT & NT \\
\hline SO4 & NT & NT & NT & NT & NT & NT & NT & NT & 23 & 11 & 23 & 11 & 23 & 11 & 20 & 10 & NT & NT & NT & NT \\
\hline S05 & NT & NT & NT & NT & NT & NT & NT & NT & 18 & 13 & 18 & 13 & 18 & 13 & 18 & 12 & NT & NT & NT & NT \\
\hline S06 & NT & NT & NT & NT & NT & NT & NT & NT & 24 & 18 & 24 & 18 & 24 & 18 & 24 & 17 & NT & NT & NT & NT \\
\hline S07 & NT & NT & NT & NT & NT & NT & NT & NT & 22 & 16 & 22 & 16 & 22 & 16 & 22 & 16 & NT & NT & NT & NT \\
\hline
\end{tabular}

W: diffusion method well variant; D: diffusion method disc variant; NT: not tested; a: values expressed in mm; b: determination of a unique value due to limited amount of pure substances.

In order to eliminate the possibility of solvents used with both variants of diffusion method to cause sensitivity differences, another experiment was performed employing diffusion method variant disc, using DMSO to dissolve extracts (DMSO was used to test variant well of diffusion method, data shown in Table 4). The results of this experiment, were compared with the values of zones of growth inhibition previously found by both diffusion method variants (discs loaded with solvents other than DMSO and well filled with DMSO) and indicated that DMSO did not cause significant difference between the two diffusion method variants, [GL(2,24); $F=12,6 ; p>0.01]$. Despite the limitations of the present study, we can assume that the results suggest that both variants display good precision. 
Table 3. Means of inhibition growth diameter obtained by diffusion method (well and disc variants) using different concentrations of natural products against Escherichia coli.

\begin{tabular}{|c|c|c|c|c|c|c|c|c|c|c|c|c|c|c|c|c|c|c|c|c|}
\hline & \multicolumn{20}{|c|}{ Concentration in $\mathrm{mg}$ (well and disc) } \\
\hline & \multicolumn{2}{|c|}{5} & \multicolumn{2}{|c|}{4} & \multicolumn{2}{|c|}{3} & \multicolumn{2}{|r|}{2} & \multicolumn{2}{|c|}{1} & \multicolumn{2}{|c|}{0.75} & \multicolumn{2}{|c|}{0.5} & \multicolumn{2}{|c|}{0.25} & \multicolumn{2}{|c|}{0.125} & \multicolumn{2}{|c|}{0.0625} \\
\hline & $\mathrm{W}^{\mathrm{a}}$ & $\mathrm{D}^{\mathrm{a}}$ & $\mathrm{W}$ & $\mathrm{D}$ & $\mathrm{W}$ & $\mathrm{D}$ & $\mathrm{W}$ & $\mathrm{D}$ & $\mathrm{W}$ & $\mathrm{D}$ & $\mathrm{W}$ & $\mathrm{D}$ & $\mathrm{W}$ & $\mathrm{D}$ & $\mathrm{W}$ & $\mathrm{D}$ & $\mathrm{W}$ & $\mathrm{D}$ & $\mathrm{W}$ & $\mathrm{D}$ \\
\hline \multicolumn{21}{|c|}{ Extracts } \\
\hline $\mathrm{E} 05$ & 12 & 9 & 11 & 0 & 11 & 0 & 9 & 0 & 0 & 0 & NT & NT & 0 & 0 & 0 & 0 & 0 & 0 & 0 & 0 \\
\hline E06 & 11 & 0 & 10 & 0 & 9 & 0 & 0 & 0 & 0 & 0 & NT & NT & 0 & 0 & 0 & 0 & 0 & 0 & 0 & 0 \\
\hline E07 & 14 & 0 & 13 & 0 & 11 & 0 & 10 & 0 & 0 & 0 & NT & NT & 0 & 0 & 0 & 0 & 0 & 0 & 0 & 0 \\
\hline E13 & 9 & 0 & 9 & 0 & 0 & 0 & 0 & 0 & 0 & 0 & NT & NT & 0 & 0 & 0 & 0 & 0 & 0 & 0 & 0 \\
\hline \multicolumn{21}{|c|}{ Substances $^{\mathrm{b}}$} \\
\hline S01 & NT & NT & NT & NT & NT & NT & NT & NT & 12 & 0 & 12 & 0 & 11 & 0 & 0 & 0 & NT & NT & NT & NT \\
\hline $\mathrm{S} 02$ & NT & NT & NT & NT & NT & NT & NT & NT & 11 & 0 & 11 & 0 & 10 & 0 & 0 & 0 & NT & NT & NT & NT \\
\hline SO4 & NT & NT & NT & NT & NT & NT & NT & NT & 15 & 0 & 11 & 0 & 10 & 0 & 9 & 0 & NT & NT & NT & NT \\
\hline S06 & NT & NT & NT & NT & NT & NT & NT & NT & 11 & 0 & 11 & 0 & 11 & 0 & 11 & 0 & NT & NT & NT & NT \\
\hline
\end{tabular}

W: diffusion method well variant; D: diffusion method disc variant; NT: not tested; a : values expressed in millimeters; $\mathrm{b}$ : determination of a unique value due to limited amount of pure substances.

Table 4. Means of inhibition zones diameter obtained by loaded discs with $5 \mathrm{mg}$ extracts dissolved in dimethyl sulfoxide (DMSO) against Staphylococcus aureus compared to those obtained by both diffusion method variants.

\begin{tabular}{|c|c|c|c|c|c|c|}
\hline & \multicolumn{6}{|c|}{ Means of zones of bacterial growth inhibition } \\
\hline $\begin{array}{l}\text { Natural } \\
\text { product }\end{array}$ & \multicolumn{2}{|c|}{ W } & \multicolumn{2}{|c|}{ DMDV } & \multicolumn{2}{|c|}{ DD } \\
\hline & Mean & SEM & Mean & SEM & Mean & SEM \\
\hline E01 & $22.0^{\mathrm{a}}$ & \pm 1.0 & 12.0 & \pm 0.0 & 12.5 & \pm 0.5 \\
\hline $\mathrm{E} 02$ & 22.5 & \pm 2.5 & 11.5 & \pm 0.5 & 15.5 & \pm 0.5 \\
\hline E04 & 16.0 & \pm 1.0 & 12.0 & \pm 0.0 & 12.5 & \pm 0.5 \\
\hline E05 & 23.0 & \pm 2.0 & 16.5 & \pm 0.5 & 17.5 & \pm 1.5 \\
\hline E06 & 17.0 & 0.0 & 11.5 & \pm 0.5 & 13.0 & 0.0 \\
\hline E07 & 20.0 & \pm 0.0 & 15.0 & \pm 0.0 & 16.5 & \pm 0.5 \\
\hline E08 & 21.0 & \pm 0.0 & 18.5 & \pm 0.5 & 18.5 & \pm 0.5 \\
\hline E09 & 19.0 & \pm 1.0 & 14.5 & \pm 0.5 & 16.0 & \pm 0.0 \\
\hline E10 & 15.5 & \pm 0.5 & 13.5 & \pm 0.5 & 14.0 & \pm 0.0 \\
\hline
\end{tabular}

W: Diffusion method well variant; DMDV: Diffusion method disc variant using solvents others than DMSO; DD: Diffusion method disc variant using DMSO as solvent; $\mathrm{SEM}=$ Standard error of the mean. a: value expressed in millimeters.

Table 5 displays results referring to standardization of two variants used for direct bioautographic method variable: incubation time of microorganism-test for the inoculum
Table 5. Tests results performed by bioautographic method direct variant using inocula of $24 \mathrm{~h}$ and $48 \mathrm{~h}$ Staphylococcus aureus grown culture and three different concentrations of indicator solution (INT).

\begin{tabular}{ccccccc}
\hline \multirow{2}{*}{$\begin{array}{c}\text { Natural } \\
\text { product } \\
(400 \mu \mathrm{gg})\end{array}$} & \multicolumn{4}{c}{ S. aureus } & \multicolumn{3}{c}{ S. aureus } \\
& $24 \mathrm{~h}$ grown culture & \multicolumn{2}{c}{$48 \mathrm{~h}$ grown culture } \\
\cline { 2 - 7 } & $0.2^{\mathrm{a}}$ & 1.0 & 5.0 & 0.2 & 1.0 & 5.0 \\
& $\mathrm{mg} / \mathrm{mL}$ & $\mathrm{mg} / \mathrm{mL}$ & $\mathrm{mg} / \mathrm{mL}$ & $\mathrm{mg} / \mathrm{mL}$ & $\mathrm{mg} / \mathrm{mL}$ & $\mathrm{mg} / \mathrm{mL}$ \\
\hline $\mathrm{E} 01$ & $10^{\mathrm{b}}$ & 9 & 10 & 8 & 10 & 9 \\
$\mathrm{E} 02$ & 6 & 6 & 8 & 6 & 6 & 6 \\
$\mathrm{E} 03$ & 11 & 10 & 11 & 10 & 10 & 9 \\
$\mathrm{E} 04$ & 12 & 10 & 11 & 8 & 9 & 10 \\
$\mathrm{E} 05$ & 09 & 10 & 10 & 10 & 10 & 10 \\
$\mathrm{E} 06$ & 7 & 7 & 8 & 7 & 7 & 8 \\
$\mathrm{E} 07$ & 6 & 6 & 6 & 4 & 5 & 4 \\
$\mathrm{E} 10$ & 0 & 0 & 0 & 0 & 0 & 0 \\
\hline
\end{tabular}

a: concentration of $p$-iodonitrotetrazolium violet salt solution (INT); b: values expressed in millimeters.

preparation and $p$-iodonitrotetrazolium violet solution concentration used as bacterial growth indicator. As indicated, no significant difference was detected among results obtained with $24 \mathrm{~h} \mathrm{~S}$. aureus grown culture inoculum compared to $48 \mathrm{~h}$ grown culture inoculum (GL14; $t=0,46 ; p>0.01$ ). Concerning to 
the other variable, results indicate that the three concentrations used for the indicator solution $(0,2 ; 1,0$ e $5,0 \mathrm{mg} / \mathrm{mL})$ were suitable to allow detection of growth (Fig. 1).

We compared two forms of establishing contact between bacteria and natural product: application of inoculum to agar before it is poured into TLC plate ("pour plate") and addition of

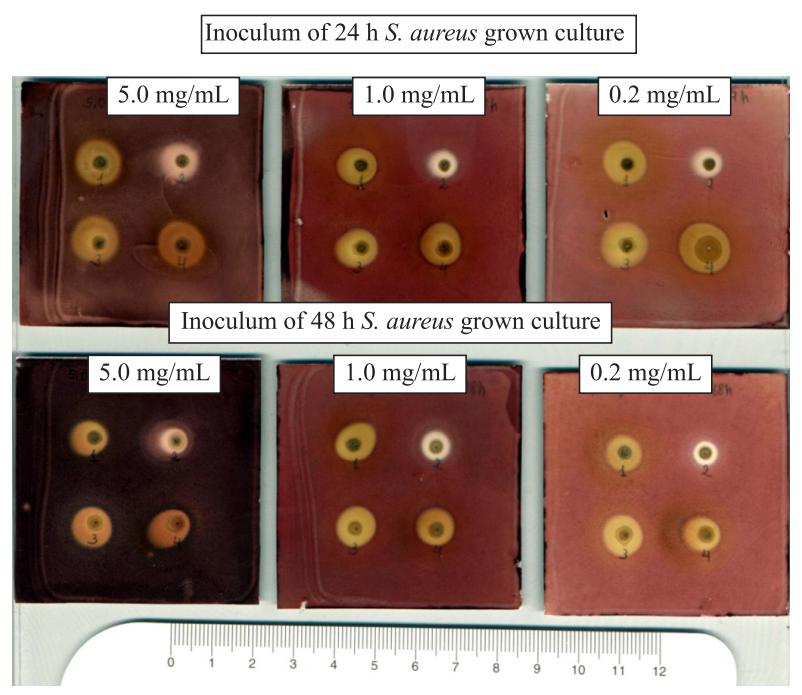

Figure 1. Results obtained using three different concentrations of indicator solution ( $p$-iodonitrotetrazolium violet salt) and two inocula of $24 \mathrm{~h}$ and $48 \mathrm{~h}$ Staphylococcus aureus grown cultures.

Table 6. Means and standard error of the means of Staphylococcus aureus zones of growth inhibition, obtained by bioautographic method indirect variant performed by swab and "pour plate" techniques

\begin{tabular}{ccccc}
\hline $\begin{array}{c}\text { Natural product } \\
(400 \mu \mathrm{g})\end{array}$ & \multicolumn{4}{c}{$\begin{array}{c}\text { Zones of growth } \\
\text { inhibition in mm }\end{array}$} \\
\cline { 2 - 5 } & \multicolumn{3}{c}{ Swab } & "Pour plate' \\
\cline { 2 - 5 } & Mean & SEM & Mean & SEM \\
\hline E01 & $10.0^{\mathrm{a}}$ & \pm 0.0 & 9.0 & \pm 0.0 \\
E02 & 7.5 & \pm 0.5 & 6.0 & \pm 0.0 \\
E03 & 11.5 & \pm 0.5 & 10.5 & \pm 0.5 \\
E04 & 10.5 & \pm 0.5 & 9.0 & \pm 0.0 \\
E05 & 11.5 & \pm 1.5 & 11.0 & \pm 0.0 \\
E06 & 8.0 & \pm 0.0 & 9.0 & \pm 0.0 \\
E07 & 10.5 & \pm 0.5 & 8.5 & \pm 1.5 \\
E08 & 12.5 & \pm 0.5 & 11.0 & \pm 0.0 \\
E13 & 7.5 & \pm 0.5 & 6.5 & \pm 0.5 \\
\hline Total & 9.9 & \pm 0.6 & 8.9 & \pm 0.6 \\
\hline
\end{tabular}

aSEM: standard error of the mean; a: values expressed in millimeters. inoculum to agar after it is poured into TLC plates. As indicated in Table 6, no significant difference was detected comparing these two ways of applying bacterial inoculum (GL16; $t=1,17$ $\mathrm{p}>0,01)$.

Table 7 shows inhibition zones diameter of $S$. aureus and E. coli growth yielded by natural products tested by direct and indirect variants of bioautographic method. Duplicate testing was not possible for fractions and pure substances due to their insufficient amount. According to evaluation of the data obtained from tests against $S$. aureus using variants of bioautographic method, it was ascertained that there was no significant difference among variables used for similar natural product concentrations, concerning antibacterial activity. Eight (88.9\%) of all nine extracts showed similar results

Table 7. Means of growth inhibition diameters of Staphylococcus aureus and Escherichia coli obtained by both direct and indirect variant of bioautographic method

\begin{tabular}{ccccc}
\hline \multirow{2}{*}{$\begin{array}{c}\text { Natural } \\
\text { product }\end{array}$} & \multicolumn{4}{c}{ Zones of growth inhibition } \\
\cline { 2 - 5 } & \multicolumn{2}{c}{ S. aureus } & \multicolumn{2}{c}{ E. coli } \\
\cline { 2 - 5 } & DB $^{\mathrm{a}}$ & $\mathrm{IB}$ & $\mathrm{DB}$ & $\mathrm{IB}$ \\
\hline Extracts $^{\mathrm{a}}$ & & & & \\
\hline E01 & $10.0^{\mathrm{b}}$ & 9.0 & 14.5 & 8.0 \\
E02 & 6.5 & 6.0 & 0.0 & 0.0 \\
E03 & 10.0 & 10.5 & 11.5 & 0.0 \\
E04 & 9.0 & 9.0 & 13.0 & 0.0 \\
E05 & 10.5 & 11.0 & 0.0 & 0.0 \\
E06 & 7.5 & 9.0 & 0.0 & 0.0 \\
E07 & 6.5 & 8.5 & 5.5 & 7.0 \\
E08 & 8.0 & 11.0 & 6.0 & 7.0 \\
E14 & 7.5 & 6.5 & 5.5 & 0.0 \\
\hline Fractions ${ }^{\mathrm{c}}$ & & & & \\
\hline F05 & 9.0 & 10.0 & 7.0 & $\mathrm{Nt}$ \\
F06 & 6.0 & 9.0 & 0.0 & $\mathrm{Nt}$ \\
\hline Pure & & & & \\
\hline substances & & & & \\
\hline S01 & 7.0 & 10.0 & $\mathrm{Nt}$ & $\mathrm{Nt}$ \\
S04 & 15.0 & 12.0 & $\mathrm{Nt}$ & $\mathrm{Nt}$ \\
S05 & 17.0 & 12.0 & $\mathrm{Nt}$ & $\mathrm{Nt}$ \\
S06 & 17.0 & 12.0 & $\mathrm{Nt}$ & $\mathrm{Nt}$ \\
S07 & 22.0 & 11.0 & $\mathrm{Nt}$ & $\mathrm{Nt}$ \\
\hline
\end{tabular}

DB: bioautographic method direct variant; IB: bioautographic method indirect variant ("pour plate" technique); NT: not tested; a: amount of natural substances used in this study (500 mg of extracts, $200 \mathrm{mg}$ of fractions and $100 \mathrm{mg}$ of pure substances); b: values expressed in millimeters; c: values of a unique measurement (tests were not performed in duplicate). 
using both variants GL $(18,19) ; \mathrm{F}=12,91 ; \mathrm{p}>0.01$. Comparisons of statistical data between both variants of bioautographic method for $E$. coli were performed only with extracts, due to limitations on amounts of fractions and pure substances (Table 9). In contrast to results obtained with $S$. aureus, significant difference in the capability of detecting antibacterial effect by both variants of bioautographic method was detected [GL (18, 19); $F=13,95 ; p<0.01]$ Six of all nine extracts were active against $E$. coli using direct variant and only 3 were active using indirect variant. In attempt to better distinguish both variants sensibility, a serial of natural products dilutions were performed and tested against S. aureus and E. coli (Tables 8, 9). As indicated in Table 8, 31.2\% of all 16 natural products serially diluted, responded to direct variant sensibility, $25 \%$ to indirect variant and $43.8 \%$ favored both variants similar sensitivity. For E. coli tests (Table 9), results demonstrate that $77.8 \%$ of assays, direct variant was more sensitive than indirect variant of bioautographic method and $22.2 \%$, both variants sensitivity was similar. Overall, direct variant proved to have higher capability of detecting antibacterial activity in
Table 9. Growth inhibition diameters of Escherichia coli obtained by bioautographic method (direct and indirect variants) using varied extracts concentrations.

\begin{tabular}{ccccccccc}
\hline \multirow{2}{*}{$\begin{array}{c}\text { Natural } \\
\text { product }\end{array}$} & \multicolumn{9}{c}{ Concentration $(\mu \mathrm{g} / \mathrm{spot})$} \\
\cline { 2 - 9 } & \multicolumn{3}{c}{500} & \multicolumn{3}{c}{200} & \multicolumn{4}{c}{50} \\
\cline { 2 - 9 } & DB & IB & DB & IB & DB & IB & DB & BB \\
\hline E01 & $10^{\mathrm{a}}$ & 8 & 8 & 6 & 6 & 0 & 0 & 0 \\
E02 & 6 & 0 & 0 & 0 & 0 & 0 & 0 & 0 \\
E03 & 10 & 0 & 8 & 0 & 6 & 0 & 0 & 0 \\
E04 & 9 & 0 & 7 & 0 & 5 & 0 & 0 & 0 \\
E05 & 10 & 0 & 8 & 0 & 7 & 0 & 0 & 0 \\
E06 & 7 & 0 & 5 & 0 & 0 & 0 & 0 & 0 \\
E07 & 6 & 7 & 0 & 0 & 0 & 0 & 0 & 0 \\
E08 & 7 & 7 & 6 & 6 & 0 & 0 & 0 & 0 \\
E14 & 7 & 0 & 5 & 0 & 0 & 0 & 0 & 0 \\
\hline
\end{tabular}

DB: bioautographic method direct variant; IB: bioautographic method indirect variant; a: values expressed in millimeters.

Table 8. Growth inhibition diameters of Staphylococcus aureus obtained by bioautographic methods (direct and indirect variants) using varied natural products concentrations

\begin{tabular}{|c|c|c|c|c|c|c|c|c|c|c|c|c|}
\hline \multirow[t]{3}{*}{ Natural product } & \multicolumn{12}{|c|}{ Concentration $(\mu \mathrm{g} / \mathrm{spot})$} \\
\hline & \multicolumn{2}{|c|}{500} & \multicolumn{2}{|c|}{200} & \multicolumn{2}{|c|}{100} & \multicolumn{2}{|c|}{50} & \multicolumn{2}{|c|}{25} & \multicolumn{2}{|c|}{12.5} \\
\hline & $\mathrm{DB}$ & $\mathrm{BB}$ & $\mathrm{DB}$ & $\mathrm{IB}$ & $\mathrm{DB}$ & $\mathrm{IB}$ & $\mathrm{DB}$ & $\mathrm{IB}$ & $\mathrm{DB}$ & $\mathrm{IB}$ & $\mathrm{DB}$ & $\mathrm{BB}$ \\
\hline \multicolumn{13}{|l|}{ Extracts } \\
\hline E01 & $10^{\mathrm{a}}$ & 9 & 9 & 8 & 8 & 7 & 7 & 6 & NT & NT & NT & NT \\
\hline $\mathrm{E} 02$ & 8 & 6 & 8 & 6 & 8 & 5 & 5 & 0 & NT & NT & NT & NT \\
\hline $\mathrm{E} 03$ & 10 & 10 & 8 & 9 & 7 & 8 & 6 & 0 & NT & NT & NT & NT \\
\hline $\mathrm{E} 04$ & 9 & 9 & 8 & 8 & 7 & 6 & 6 & 0 & NT & NT & NT & NT \\
\hline E05 & 9 & 11 & 6 & 10 & 0 & 9 & 0 & 8 & NT & NT & NT & NT \\
\hline E06 & 7 & 9 & 6 & 8 & 5 & 6 & 0 & 0 & NT & NT & NT & NT \\
\hline E07 & 6 & 10 & 0 & 7 & 0 & 5 & 0 & 0 & NT & NT & NT & NT \\
\hline E08 & 8 & 11 & 6 & 8 & 0 & 7 & 0 & 6 & NT & NT & NT & NT \\
\hline E14 & 8 & 7 & 8 & 7 & 6 & 6 & 5 & 5 & NT & NT & NT & NT \\
\hline \multicolumn{13}{|l|}{ Fractions } \\
\hline F05 & NT & NT & 9 & 10 & 7 & 7 & 0 & 6 & 0 & 0 & NT & NT \\
\hline F06 & NT & NT & 6 & 9 & 6 & 8 & 6 & 7 & 0 & 6 & NT & NT \\
\hline \multicolumn{13}{|l|}{ Pure substances } \\
\hline S01 & NT & NT & NT & NT & 7 & 10 & 7 & 6 & 7 & 0 & 7 & 0 \\
\hline S04 & NT & NT & NT & NT & 15 & 12 & 12 & 12 & 11 & 11 & 7 & 9 \\
\hline S05 & NT & NT & NT & NT & 17 & 12 & 15 & 12 & 14 & 11 & 12 & 11 \\
\hline S06 & NT & NT & NT & NT & 17 & 12 & 16 & 12 & 14 & 12 & 12 & 11 \\
\hline S07 & NT & NT & NT & NT & 22 & 11 & 20 & 11 & 16 & 11 & 13 & 10 \\
\hline
\end{tabular}

DB: Bioautographic method direct variant; IB: Bioautographic method indirect variant; NT: not tested; a: values expressed in millimeters. 
smaller concentrations of natural products (more sensitive). Under definite conditions, results using both variants of bioautographic method showed good reproducibility proving good precision of the assay.

In the present study, if we compare results listed in Tables 2 and 8 (referred to $0.5 \mathrm{mg}$ extracts assayed by both screening tests) and consider $9 \mathrm{~mm}$ diameter as breakpoint for implying active extracts (18)(diffusion method criteria) then we can notice that six extracts tested showed to be active against $S$. aureus by diffusion method and seven extracts by bioautographic method. Nevertheless, if we consider diffusion method well variant and bioautographic method direct variant, as parameters for comparison, we can observe that the same six extracts were active by the first method while only five extracts were active by second method. Therefore, according to results, there was no significant difference between the employed methods.

As indicated in Table 10, there was no difference among results yielded by both culture mediums. MHB medium is still used in our laboratory because of its fast and easy preparation. In order to assure fidelity of the obtained results, tests are read by two methodologies: optical density measurement (ELISA reader) and colorimetric assay for detection of bacterial growth (INT). These combined procedures were adopted because ELISA methodology allows successive determination of minimum bactericidal concentration (MBC) values and colorimetric assay allows confirmation of ELISA reader results in case of testing a not completely vehicle-soluble or colorful compound.

Table 10. Minimum inhibitory concentration (MIC) of lichen and fungi substances against Staphylococcus aureus and Escherichia coli.

\begin{tabular}{ccccc}
\hline \multirow{2}{*}{$\begin{array}{c}\text { Natural } \\
\text { product }\end{array}$} & \multicolumn{4}{c}{ MIC } \\
\cline { 2 - 5 } & \multicolumn{2}{c}{ S. aureus } & \multicolumn{2}{c}{ E. coli } \\
\cline { 2 - 5 } & MH & LB & MH & LB \\
\hline S01 & $500^{\mathrm{a}}$ & 500 & 500 & 500 \\
S02 & 500 & 500 & $>1000$ & $>1000$ \\
S03 & 62.5 & 62.5 & $>1000$ & $>1000$ \\
S04 & 125 & 125 & $>1000$ & $>1000$ \\
S05 & 62.5 & 62.5 & $>1000$ & $>1000$ \\
S06 & 250 & 250 & $>1000$ & $>1000$ \\
S07 & 15.63 & 15.63 & $>1000$ & $>1000$ \\
S09 & 1000 & 1000 & $>1000$ & $>1000$ \\
S10 & 1000 & 1000 & $>1000$ & $>1000$ \\
S11 & 1000 & 1000 & 1000 & 1000 \\
\hline
\end{tabular}

a: value expressed in $\mu \mathrm{g} / \mathrm{mL}$.

\section{DISCUSSION}

The results shown in Tables 2, 3, and 4 pointed to better sensibility of diffusion method variant well rather than variant disc. Besides, additional arguments are in favor of the preferential use of the first variant for the screening of natural products with antibacterial activity. The hole plate method is the only suitable diffusion technique for testing aqueous suspensions of plant ethanol extracts (20). In this method, the presence of suspended particulate matter in the sample being tested is much less likely to interfere with the diffusion of the antimicrobial substance into the agar than in the filter paper disc. Precipitation of water-insoluble substances in the disc will indeed prevent any diffusion of antimicrobial substances into the agar. Little time consuming and simplicity are stimulating reasons for the use of diffusion method variant well rather than variant disc. In general, both diffusion method variants are similar to each other in terms of cost, although discs variant may be a little more expensive because of the price of paper filter Whatman, which is composed of cellulose [b-(1-4) linked glucose monomers]. The many free hydroxyl groups present on each glucose residues renders the surface of the disc hydrophilic (3). Thus, if natural products were cationic, they would be expected to adsorb to the surface of the disc and not diffuse into the medium. Consequently, a cationic polar compound may display a good antibacterial activity, but which is therefore not noticeably antibacterial by paper disc diffusion method. Apolar compounds would not be influenced by the hydroxyls on the surface of the paper and would diffuse easily. Thus, in this case, well agar diffusion method is more convenient than the disc variant. This theory explains at least in part, the higher sensitivity detected by well agar diffusion method. Also, the fact that the well variant yielded larger growth inhibition zones might be related to natural products transport by carrier compounds such as DMSO, for it is expected that they diffuse easily across the medium. Concerning the disc variant, diffusion may probably occur by capillarity (by water within the medium from solvatation process), once the solvent used to dissolve the natural products is evaporated before placing discs on the surface of the agar. The diffusion process may be defined as the process by which molecules intermingle as a result of their kinetic energy of random motion from high concentrations areas to lower ones. The diffusion process depends on numerous factors including number, size and shape of particles (10). Number of particles is an important factor: the molecules diffuse faster at higher gradient of concentration. Particle volume influences diffusion rate as well: small particles will diffuse faster and large ones will diffuse slower. As the molecule radius increases we expect diffusivity to decrease proportionally to radius-squared because of solute-solvent increased interactions. Also, as temperature rises, diffusion process is enhanced, because of increased average kinetic energy of molecules. Time 
is another parameter which influence diffusion rate. The distance reached by diffused molecules is approx. proportional to the inverse of time squared. In an effort to lower the detection limit, Onawunmi et al. (14), have been allowing the inoculated system to be idle at $\pm 4^{\circ} \mathrm{C}$ for many hours before incubation (at $36^{\circ} \mathrm{C}$ ), thus favoring diffusion process over bacterial growth. In the present work, this procedure has been ignored since diffusion rate is directly proportional to temperature values, as mentioned above. Moreover, a decrease in temperature values favors precipitation of antibacterial compounds causes diffusion rate limiting (2). Besides polarity of samples, also the $\mathrm{pH}$ of solvents should be checked before testing, since microbial growth might be hindered in media which have been rendered too acid or too alkaline by samples. Furthermore, the antibacterial activity of active substances can be altered by small $\mathrm{pH}$ switches. In practice, extracts are best adjusted to neutrality (between $\mathrm{pH}$ 6.0 and 8.0) or dissolved in buffer solutions (2). In our study, the aim was to make comparisons between diffusion methods variants rather than evaluate the natural products activity, and therefore, $\mathrm{pH}$ parameter was disregarded. Although, considering all the advantages of the well diffusion method presented in this work, one must be aware of the limitations of this method. Diffusion methods are not the best choice for testing non-polar or other samples, which are difficult to diffuse in the media. Aqueous dispersions containing high molecular weight solubilisers (mol. wt $>100.000$ Daltons) should be avoided in diffusion methods since they cannot diffuse into $1 \%$ de agar media. In those cases, employment of alternative methods as direct bioautography or semi-quantitative dilution methods is suggested (2).

We exploited topic about inoculum preparation in the present study (Table 5, Fig. 1), due to poorly detailed procedures reported in a number of consulted studies $(1,13)$. Tetrazolium salt suitable concentration to be used in tests was studied because of the wide range variation in the salt concentration found in literature (Fig. 1). Some researchers $(5,13)$ employed $2 \mathrm{mg} / \mathrm{mL}$ salt solution, others preferred to use a $5 \mathrm{mg} / \mathrm{mL}$ solution (9). According to obtained results, $24 \mathrm{~h}$ grown bacterial culture for inoculum preparation and indicator solution concentration of $0.2 \mathrm{mg} / \mathrm{mL}$ were set as standard patterns (Table 5, Fig. 1). Time and resources are gained when theses two procedures are adopted, for the cost of tetrazolium salt is relatively high. It is known that " $p$ iodonitrotetrazolium violet" (INT), "tetranitro blue tetrazolium" (TNBT) and "methyl thiazolyl tetrazolium" (MTT) proved to be good substrates for enzimatic reactions (2). However, comparing these three salts the use of INT is preferred because in contrast to others, it is colorless, facilitating bioautogram evaluation (9). In addition, we adopted INT as indicator because of the simplicity in preparing INT in $70 \%$ ethanol solution. It is convenient to emphasize the antiseptic property of ethanol diminishing contamination risk when carrying out system-tests. It is reported that "formazan" deposits yielded by the enzimatic reactions, increase with time and recommend a $4 \mathrm{~h}$ incubation of systems sprayed with INT (9). However, $2 \mathrm{mg} / \mathrm{mL}$ of INT solution was sprayed on TLC plates before incubation was held at $100 \%$ relative humidity for $30 \mathrm{~min}$ before reading results (21). Initially, our first system-tests were incubated for $6 \mathrm{~h}$. In the first hour, it was possible to distinguish bacterial growth zones of inhibition. Nonetheless, the suggestion from some authors (9) was adopted and we kept the systems incubating for $4 \mathrm{~h}$, and the increasing of color intensity occurred and after that period, the area covered of bacterial growth did no longer undergo color variations. Furthermore, we used a concentration 10 times lesser than that used by some workers (21). Different procedures have been found in literature referring to the way of bringing bacterial suspension in contact with TLC plates: some authors sprayed bacterial suspension on TLC plates (12), and some dipped the TLC plates into bacterial inoculum $(4,6)$. We opted for the latter technique, once it keeps microorganisms locked into closed systems instead of being in contact with environmental air. The preference for silica gel $\mathrm{G}_{60} \mathrm{~F}_{254} \mathrm{TLC}$ plate was based on a research which reports that polyamide and aluminum oxide used as stationary phases, beard poor results (9).

In this work, we also compared the sensibility between direct and indirect variants of bioautography method. As shown in Tables 7, 8, and 9 the direct variant results are outstanding. This variant is more sensitive and easy to develop. However, in case of use of indirect variant, we recommend the application of the inoculum on surface of the agar (Table 6).

The bioautography assay may represent a useful tool for purification of antibacterial substances if tests are performed through the use of chromatograms. Bioautography allows easy localization of activity even in complex matrix as that derived from natural products (9). Developed chromatogram comparison under identical conditions and visualized with the use of suitable chromogen reagent can provide useful information about nature of active compounds.

An advantage of bioautographic method is the possibility of using mobile phases containing solvents of low volatility as $n$-butanol, in case of its complete removal before carrying out tests. However, too acid or too alkali solvents remain on TLC plate after long drying time, inhibiting possible bacterial growth (9). Besides all known advantages of bioautographic method, one must remind that diffusion test is the most accepted method from the microbiological aspect, once nutritional adequacy may be adjusted according to microorganisms-test requirements and there is no electrical field caused by negative or positive charges whose possible effect on microbial metabolism has not been yet fully elucidated. Thus, results analysis from sensible and functional aspect, suggest the employment of diffusion method well variant.

Microdilution method can be used as semi-quantitative or quantitative assay, depending on the aim of the testing (for 
screening or determination of minimum inhibitory concentrationMIC). Aside the fact that this method is laborious, its use is suitable for determining MIC of pure substances. Initially, when MIC tests were first performed at Laboratório de Antibióticos, Universidade Federal de Santa Catarina, $200 \mu \mathrm{L}$ volumes per well plus $0.5 \%$ agar were added, in order to avoid evaporation loss, modification of concentration of substances and precipitation of vehicle-insoluble particles (7). Subsequently, these procedures were put aside and new methodology was adopted using liquid medium (Mueller-Hinton broth), $100 \mu \mathrm{L}$ per well (19). MuellerHinton broth (MHB) and Luria Bertania (LB) are commonly used media in literature on MIC determination.

In conclusion, the results indicate that agar well diffusion method proved to be more sensitive than disc diffusion method. Like wise, according to the presented results, direct bioautographic method showed to be more sensitive than the indirect variant. Also, preparation of the bacterial inoculum from $24 \mathrm{~h}$ grown culture, rather than $48 \mathrm{~h}$, is suitable for performing the tests by bioautographic method and a concentration of 0.2 $\mathrm{mg} / \mathrm{mL}$ of $p$-iodonitrotetrazolium violet indicator solution is eligible to allow visualization of results. These two procedures take relatively little time to perform and save financial resources (once the cost of tetrazolium salt is in general, elevated). Based on the results we obtained, concerning MIC determination, choice for MH or LB broth depends on the criteria of the investigator. Nevertheless, the growth indicator use (i.e. INT) is required in situations when natural products are colorful or not completely vehicle-soluble. ELISA reader allows reading $\mathrm{MBC}$ results after MIC determination.

\section{RESUMO}

\section{Métodos de triagem para determinação de atividade antibacteriana de produtos naturais}

Com o surgimento de novas doenças infecciosas, o reaparecimento de várias infecções que pareciam ter sido controladas, e o aumento da resistência bacteriana houve a necessidade de pesquisas dirigidas ao desenvolvimento de novos antimicrobianos. Levando em consideração a dificuldade de aquisição de novas moléculas com atividades antimicrobianas, a otimização de métodos de triagem usados na identificação de antimicrobianos de fontes naturais é de grande importância. O objetivo deste estudo foi avaliar variantes técnicas, usadas em métodos de triagem para determinar atividade antibacteriana de produtos naturais. Assim, vários produtos naturais, oriundos de plantas, fungos e líquens foram testados contra duas espécies bacterianas, Staphylococcus aureus ATCC 25923 e Escherichia coli ATCC 25922, por duas variantes do método de difusão em ágar (poço e disco), duas variantes do método bioautográfico (direto e indireto) e por testes de microdiluição. Concluímos que a variante do método de difusão variante poço foi mais sensível do que a variante disco, enquanto que a variante direta do método bioautográfico exibiu uma sensibilidade maior, comparada com a variante indireta. As técnicas de bioautografia e difusão mostraram sensibilidades similares, embora a última tenha fornecido condições mais apropriadas para o crescimento bacteriano. Neste estudo, também discutimos as melhores condições para a determinação da concentração inibitória mínima.

Palavras chaves: Difusão em ágar, atividades antimicrobianas, bioautografia, concentração inibitória mínima, concentração bactericida mínima, produtos naturais.

\section{REFERENCES}

1. Afolayan, A.J.; Meyer, J.J.M. (1997). The antimicrobial activity of 3, 5, 7-trihydroxyflavone isolated from the shoots of Helichrysum aureonitens. J. Ethnopharmacol., 57, 177-181.

2. Beghe, W.J.; Kline, R.M. (1972). The use of tetrazolium salts in bioautography procedures. J. Chromatogr., 64, 182-184.

3. Burgess, J.G.; Jordan, E.M.; Bregu, M.; Mearns-Spragg, A.; Boyd, K.G. (1999). Microbial antagonism: a neglected avenue of natural products research. J. Biotechnol., 70, 27-32.

4. Caccamese, S.; Cascio, O.; Compagnini, O. (1989). An isolation of an antimicrobial bromoditerpene from a marine a alga aided by improved bioautography. J. Chromatogr., 478, 255-258.

5. Eloff, J.N. (2001). Antibacterial activity of Marula (Sclerocarya birrea (A. rich.) Hochst. Subsp. caffra (Sond.) Kokwaro) (Anacardiaceae) bark and leaves. J. Chromatogr., 76, 305-308.

6. Falch, B.S.; Konig, G.M.; Wright, A.D.; Sticher, O.; Angerhofer, C.K.; Pezzuto, J.M.; Bachmann, H. (1995). Biological activities of cyanobacteria: Evaluation of extracts and pure compounds. Planta Méd., 61, 321-328.

7. Gomes, A.T.; Smânia, Jr. A.; Seidel, C.; Smânia, E.F.A.; Honda, N.K.; Roese, F.M.; Muzzi, R.M. (2003). Antibacterial activity of orsellinates. Braz. J. Microbiol., 34, 194-196.

8. Hadacek, F.; Greger, H. (2000). Testing of antifungal natural products: methodologies, comparability of results and assay choice. Phytochem Anal., 11, 137-147.

9. Hamburger, M.O.; Cordell, G.A. (1987). A direct bioautographic TLC assay for compounds possessing antibacterial activity. J. Nat. Prod. $50,19-22$.

10. Heneine, I.F. 2000. Biofísica Básica, Atheneu, São Paulo.

11. Hostettman, K.; Wolfender, J.L.; Rodriguez, S. (1997). Rapid detection and subsequent isolation of bioactive constituents of crude plant extracts. Planta Med., 63, 2-10.

12. Martini, N.; Eloff, J.N. (1998). The preliminary isolation of several antibacterial compounds from Combretum erythrophyllum (Combretaceae). J. Ethnopharmacol., 62, 255-263.

13. Nostro, A.; Germanò, M.P.; D'Angelo, V.; Marino, A.; Cannatelli, M.A. (2000). Extraction methods and bioautography for evaluation of medicinal plant antimicrobial activity. Lett. Appl. Microbiol., 30 379-384

14. Onawunmi, G.O.; Yisak, W.; Ogunlana, E.O. (1984). Antibacterial constituents in the essential oil of Cymbopogon citratus (DC.) Stapf. J. Ethnopharmacol., 12, 279-286.

15. Recio, M.C.; Rios, J.L. (1989). A review of some antimicrobial compounds isolated from medicinal plants reported in the literature 1978-1988. Phytoter. Res., 3, 117-125.

16. Rios, J.L.; Recio, M.C.; Villar, A. (1988). Screening methods for natural products with antimicrobial activity: a review of the literature. J. Ethnopharmac., 23, 127-149. 
17. Silver, L.L.; Bostian, K.A. (1993). Discovery and development of new antibiotics: the problem of antibiotic resistance. Antimicrobial Agents Chemother., 37, 377-383.

18. Smânia, A.; Monache, F.D.; Smânia, E.F.A.; Cuneo, R.S. (1999). Antibacterial activity of steroidal compounds isolated from Ganoderma applanatum (Pers.) Pat. (Aphyllophoro-mycetideae) Fruit body. Int. J. Med. Mushrooms, 1, 325-330.

19. Souza, S.M.; Delle-Monache, F.; Smânia, Jr. A. (2005). Antibacterial activity of coumarins. Z. Naturforsch., 60, 693-700.
20. Vanden Berghe, D.A.; Vlietinck, A.J. (1991). Screening methods for antibacterial and antiviral agents from higher plants. In: Dey, P.M., Harbone, J.D. (eds), Methods in Plant Biochemistry, Academic Press, London, p. 47-69.

21. Yff, B.T.; Lindsey, K.L.; Taylor, M.B.; Erasmus, D.G.; Jager, A.K. (2002). The pharmacological screening of Pentanisia prunelloides and the isolation of the antibacterial compound palmitic acid. $J$. Ethnopharmacol., 79, 101-107. 